\title{
Rainwater Quality Index of Selected Communities in Langtang North and South Local Government Areas, Plateau State North-Central Nigeria
}

\author{
Badamasi Jamda Saidu, ", Daniel Davou Dabi ${ }^{2}$, Augustine Chukwuma Eziashi ${ }^{2}$, \\ Mahmud Mohammed Bose ${ }^{1}$ \\ ${ }^{1}$ Department of Geography, Federal University of Kashere, Kashere, Nigeria \\ ${ }^{2}$ Department of Geography and Planning, University of Jos, Jos, Nigeria \\ Email address: \\ badamasi09@gmail.com (B. J. Saidu) \\ ${ }^{*}$ Corresponding author
}

\section{To cite this article:}

Badamasi Jamda Saidu, Daniel Davou Dabi, Augustine Chukwuma Eziashi, Mahmud Mohammed Bose. Rainwater Quality Index of Selected Communities in Langtang North and South Local Government Areas, Plateau State North-Central Nigeria. Science Journal of Analytical Chemistry. Vol. 9, No. 1, 2021, pp. 18-25. doi: 10.11648/j.sjac.20210901.12

Received: June 11, 2020; Accepted: July 29, 2020; Published: January 12, 2021

\begin{abstract}
This study examines the portability of rainwater in Langtang north and south LGAs of Plateau State-Nigeria using arithmetic water quality index method with 10 samples collected directly from zinc and aluminum rooftops in 10 selected communities. Twenty-six water quality parameters were analyzed in the field and laboratory. Temperature, $\mathrm{pH}, \mathrm{EC}, \mathrm{TDS}$ and turbidity were analyzed in the field using appropriate equipment as well as color, odour and taste. The most probable number was used to determine the presence of bacteria, while photometric and the Atomic Absorption Spectrophotometer (AAS) were used to determine the concentration of the various chemical parameters (USEPA, 2012). The results revealed unobjectionable taste, color and odour, temperature (26.8-27.5), $\mathrm{pH}$ (6.5-7.8), Turbidity (1.8-2.7), Conductivity (20-30), TDS (10-15), Caco 3 (510), $\mathrm{Ca}(2-8), \mathrm{Mg}(1-4), \mathrm{SO}_{4}(1-7), \mathrm{NO}_{3}$ (1.3-8.6), Fe (0.01-0.15), Cl (10-32), F (0.001-0.002), Cu (0.01-0.2), Zn (0-1.5), Mn (0-0.02), Cr (0-0.01), Al (0.01-0.06), and total coliform (0-4). Cadmium, Arsenic, Lead, phenols, pesticides, faecal coliform and e-coli were not detected. All parameters tested were within acceptable limits for drinking water. While aluminium catchments do not show any difference in parameter concentrations, zinc catchment revealed increase in $\mathrm{Zn}$ concentration with age of materials. Calculated water quality index of samples ranged from 2 to 12 with an overall value of 4.7 indicating excellent water quality for all samples. Based on these results, the paper concludes that the rainwater is of good quality suitable for drinking. However, age of catchment materials may influence rainwater quality in due course through leaching, and therefore recommended regular maintenance of catchments, observance of first flush and avoid use of old roof for RWH.
\end{abstract}

Keywords: Water Quality Monitoring, Drinking Water Safety, WQI, Roof Catchment

\section{Introduction}

The role play by fresh water for the existence of living organisms cannot be over emphasized. Gleick; "[1] has maintained that Safe drinking water is a human birth right", but fresh water is increasingly being threatened as human populations grow and demand for more high quality water also increases. The UN observed that 2.5 billion of the world population does not have access to adequate safe drinking water [2]. The Sub-Saharan Africa according to Falkinmark accounts for $40 \%$ global population without access to safe drinking water [3]. The only public water supply scheme in the study area, the Langtang Water Board Commissioned in 1983, stopped functioning in 2012 due to faulty equipment and residence access water from sources such as dams, ponds, streams, dug-wells and boreholes. Gongden and Lohdip noted frequent drought and changing climatic pattern have led to seasonality of stream flow, drying of dams and reduction in groundwater yield that result in occasional scarcity [4], while increasing population has exacerbated the water shortages. Therefore, most residents undertake rainwater harvesting $(\mathrm{RWH})$, an ancient practice of capturing 
and storing rainwater for later use to augment other sources. Dellman et al has argued that the management of RWH is flexible and sustainable as simple inexpensive technologies that are easy to maintain are mostly used, and it is considered one of the cleanest source of water [5]. Besides, the gradual shift from the traditional thatched houses to the use of modern roofing materials such as zinc and aluminum sheets which facilitate rainwater collection also encourage increase of RWH in Langtang, but how safe is the water for man consumption since contaminants within the collection system can affect its quality? This cannot be answered without adequate data which is currently not available. Therefore, the objective of this study is to analyze rainwater quality of the study area to determine its suitability for human consumption in line with acceptable standard. This is because the quality of any water body according to Saidu et al is never known by mare look with the naked eye except through analysis with appropriate instrument [6].

\section{Literature Review}

Rainwater is usually of high quality when falling from the sky, but when it get near the earth it comes into contact with different surfaces such as buildings, trees, grasses, roadways, water bodies, parking lots and atmospheric gases among others. Therefore, the quality of rainwater as observed by Aladenola and Adeboye, largely depends on geographic location, catchment characteristics, atmospheric gases, land use practices, local climate, and storage materials [7]. Environmental factors like pollutants from atmosphere, roadways, and wind-blown objects can affect rainwater quality negatively. Besides, Amponsah et al, noted combustion of fuels for energy generation, transportation, heating for industrial needs, wind-blown soils from arid and agricultural regions, volatilization from agriculture and poor waste disposal can also affect rainwater [8]. Nangbes et al as well as Chukwuma et la, found high ammonium and acidic rainwater due to release of hazardous gases in atmosphere from vehicular traffic, local urban and industrial emissions [9-11]. Also, Jamal et al and Zhang et al found high arsenic and mercury in rainwater of urban and industrialized areas from impurities absorbed in the atmosphere, and pesticides, Aromatic polycyclic hydrocarbons (PAHs) [12, 13]. Differences in climate and human activities can create variation in rainwater quality from one location to another. Emerole and Emerole had statistically significant difference in $\mathrm{SO} 4$, turbidity, $\mathrm{PO} 4, \mathrm{Cr}, \mathrm{Cd}, \mathrm{Pb}, \mathrm{NO}_{3}$, carbonate and $\mathrm{pH}$ to climatic differences [14], while Godwin reported similar result for $\mathrm{Cd}, \mathrm{Ni}, \mathrm{Fe}, \mathrm{Cr}$, and low $\mathrm{pH}$ to environmental differences [15].

Rooftop catchment according Uzomaka, can provide good quality rainwater, clean enough for drinking as long as the rooftop is clean, impervious and made from non-toxic materials [16]. However, contaminants can be introduced in rainwater either through washing-off of contaminants collected on catchments between rain events such as leaves and pollen from plants, fecal droppings from animals like birds, squirrels and insects or leaching of chemicals and/or metals from the catchment material. Heavy metals like $\mathrm{Cd}$, $\mathrm{Zn}, \mathrm{Cu}, \mathrm{Pb}, \mathrm{As}, \mathrm{Ni}$ and $\mathrm{Cr}$ have been detected in rainwater collected from rooftops due to phenomenon of acid rain according to Uzomaka et al, and Basak and Algha, causes chemical leaching of roof materials with five times solubility in some cases under acidic conditions than neutral in Istanbul, Lagos, New Zeeland and Ghana [16-19]. Therefore, one way of ensuring better rainwater quality is avoiding roof materials such as copper, aged and materials coated with metals and/or treated with fungicides that may release contaminants into the collection system.

Studies by Simmons et al, Bello and Nike, and Rahman et al have reported microbial pollution of rainwater with Fecal coliform, Total coliform, E-coli, Salmonella spp, Enterococcus spp, Giardia lambia, Pseudomonas spp and Cryptosporidium in both urban and rural areas [20, 21, 17]. Roof runoff: "[ $[16 ; 6 ; 19]$ is also affected by roof orientation to sunlight, wind direction, Land use, and rainfall intensity and quantity. The extents to which roofing materials affect rainwater quality vary. Studies; "[22 \& 23] found Alluminum rooftops with better rainwater quality to corrugated plastics, asbestos, concretes and corrugated iron sheet. Similarly, "[18; 13] wooden shingle had better quality than cotta clay roof, zinc and galvanized roofs, while ceramic tiles better than concrete, asphalt, and green roofs".

Like catchments, storage media also leached contaminants in stored rainwater which vary from one material to another. Significant variation in $\mathrm{pH}, \mathrm{EC}$, TDS, biological parameters, and some metals was reported in metal, plastic and concrete tanks with plastics tanks having highest microbial contamination due to low $\mathrm{pH}$ [24]. Elevated levels; “[25;26] of chemical parameters due to leaching from storage tanks as well as biological parameters above limits have been reported. Researches have proved that rainwater quality can be improved by point-of-use treatment, integration of water safety plans, utilization of weather-resistant materials like ceramic tiles as catchment, regular maintenance of catchment $[13,18]$. First-flush diversion which several gallons of rooftop runoff are allowed to washed dirt before collection and regular maintenance of storage tanks can significantly assist to ensure better rainwater quality.

\section{Material and Methods}

\subsection{The Study Area}

Langtang North and South Local Government Areas (LGAs) often called Langtang area, is located in the lowland part of Plateau State about $200 \mathrm{~km}$ south of Jos the State capital, and falls within latitudes $8020^{\prime} 00^{\prime \prime}$ and $9040^{\prime} 00^{\prime \prime}$ north and longitudes 9030'00" and 10010'00" east. It has land mass of 1,626 sqkm and share boundaries with Kanke, Kanam, Pankshin, Mikang, Shendam LGAs as well as Nassarawa and Taraba States (Figure 1). The area has sub-humid climate like the neighboring Nassarawa and Taraba States due to similarities in elevation with mean low and high temperature 
of $260 \mathrm{C}$ and $300 \mathrm{C}$ respectively. The lowest temperature is recorded between December and January, when the dry Harmattan wind from the Sahara Desert dominates the climate scene, and peak of rainy season in August and September. However, in March and April when the south west trades wind approaches from the south, the north easterly weakens, and both temperature and relative humidity rises. Average monthly and annual relative humidity ranges between 20 and 28 with March and April as the hottest months. Mean high and low monthly rainfall range between
$5 \mathrm{~mm}$ and $50 \mathrm{~mm}$, while Mean annual rainfall in the area is between 165 and 322. The highest rainfall of $400 \mathrm{~mm}$ is recorded in August and July with 322, while March, April and November have lowest rainfall with annual record of $11.36 \mathrm{~mm}, 29.98 \mathrm{~mm}$ and $11.62 \mathrm{~mm}$ respectively. The annual total rainfall of the area ranges between $1000 \mathrm{~mm}$ to $2000 \mathrm{~mm}$. Early and late onset of rain is March and early May respectively, while cessation of rains are early October and middle of November in that order.

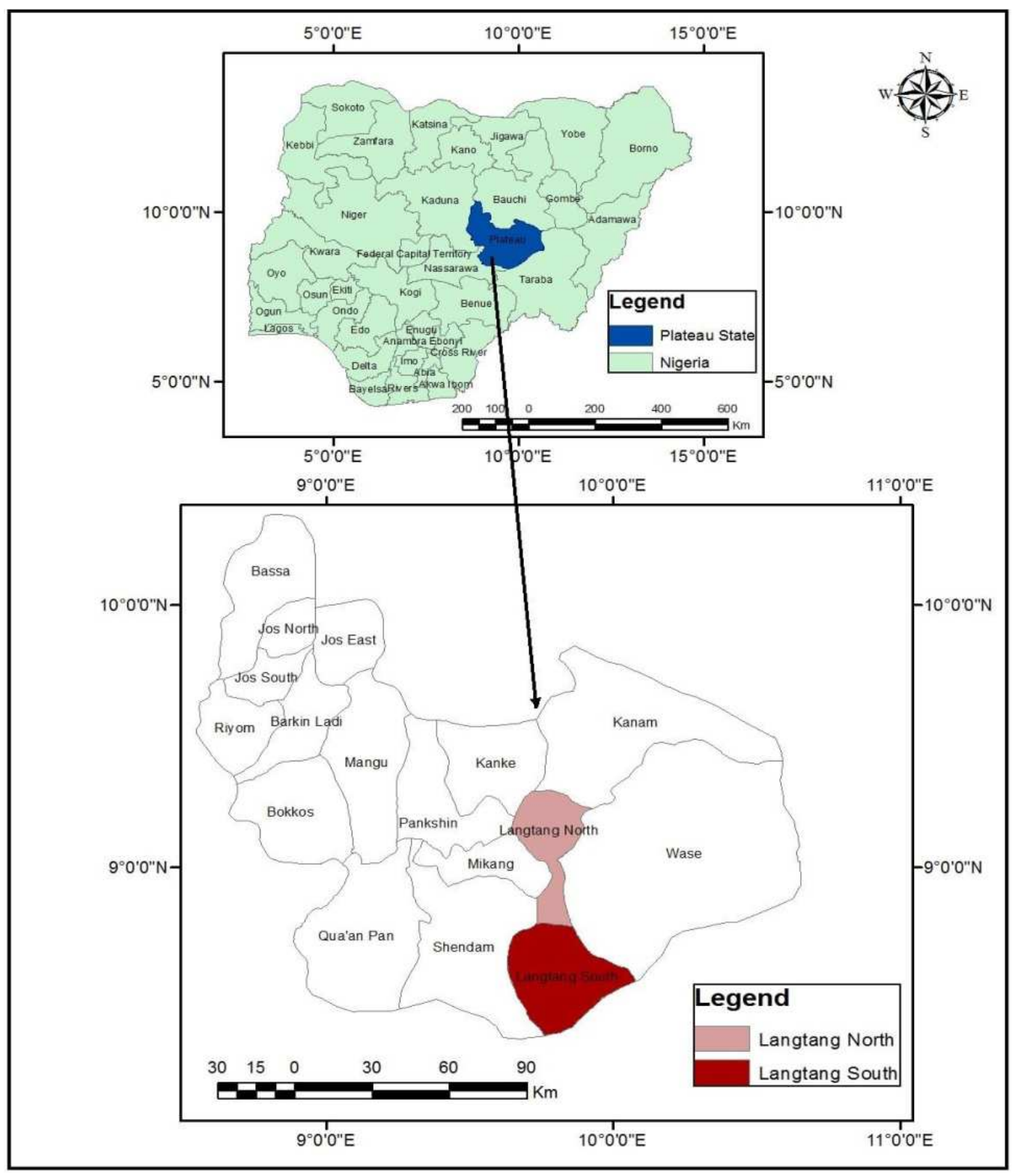

Figure 1. Plateau State; Study Area (Insert Nigeria and Plateau).

The relief is composed of uplands and lowlands created by interplay of tectonic elevation and erosion now intensified by deforestation and deep differential chemical weathering of rocks [28]. The uplands at the extreme north-west with average elevation of 500 amsl are composed of hills, mountains, and undulating terrains. The lowland from middle Langtang north to the whole of Langtang south has average elevation of 150 amsl, characterized by plain land with pockets of outcrops of basement complex rocks and isolated hills. Major drainages in the area are rivers Wase and Shemankar and their tributiers such as Pil-Gani, Bapkwai, Zamko etc with dentritic pattern. Located within guinea savannah zone of Nigeria, the original vegetation characterized by tall trees inter-spaced with tall grasses has 
been replaced by a grassy savannah with occasional shrubs due to man interference through land clearance and burning for farming, firewood and grazing. This resulted in regrown vegetation at various levels but the original woodland vegetation (gallery forest) is still found along major streams. Most trees are deciduous, examples include; Shea butter, locust bean, isoberlina, and baobab. Land use in the area is dominated by crop cultivation in line with the occupation of over $80 \%$ of people, followed by livestock grazing and settlements. Farming method is mainly non-mechanized, and major crops are; maize, guinea corn, millet, rice, groundnut, soya beans, hot and sweet pepper.

Langtang is the home of Tarok ethnic group who constitutes over $90 \%$, but other ethnic groups like Bogghom, Gomei, Gargaye, Tal among others are found in smaller numbers. Residents are predominantly peasant farmers with few combining farming with trading, public service, blacksmithing, hunting, carving, basketry, pottery, weaving, and animal husbandry. Settlements are mainly rural in nature with dispersed pattern and few nucleated. Aerial distribution of the settlements is strongly controlled by security, presence of arable land and water availability. There is no public water supply scheme in the entire study area. Domestic water needs are obtained from dug wells, boreholes, streams, ponds, dams and lakes. Due to poor lithology, most groundwater sources have low yield while some the surface either dry off completely the witness significant reduction in volume during dry season. Hence, there is annual circle of severe water scarcity during dry season and drought period in the area leading to low access to water. Women and the girl child spend a better part of the day in search of water in most rural communities during dry season, the situation has reached a point where girls find it difficult to accept marriage proposals from communities with worst cases, owing to the fact that they may spend most parts of their lives looking for water (Mr Dandam Gyemkum, personal Communication, 20th April 2018). Rainwater harvesting is undertaken to augment domestic water supply sources.

\subsection{Sample Collection and Laboratory Tests}

Two days reconnaissance to get acquainted with the settings of the area such as terrain, road networks, settlement distributions and rainwater catchments which aided adequate gathering of equipment and planning of route for the main field work was undertaken. Three community key informants were identified and engaged in this survey. The informants facilitated the conduct of the preliminary survey through provision of relevant information, guides, movements and arrangement of meetings with stakeholders for permission.

Ten rainwater samples, five each from zinc and aluminium rooftops were collected in 10 selected communities of PilGani, Gazum, Batkilang, Bapkwai, Zamko, Mabudi, Nassarawa, Magama, Faya and Barrack. Purposely sampling method was used to ensure spread with five communities in each of the LGAs under study. Samples were collected directly into $1000 \mathrm{ml}$ plastics containers previously cleaned with dilute acid solution and rinsed with distilled water during rains from $7^{\text {th }}$ to $12^{\text {th }}$ September, 2018. Samples were acidified with $5 \mathrm{ml}$ Nitric acid $\left(\mathrm{HNO}_{3}\right)$, stored in cooler with ice packs and transported to laboratory. This was to preserve the samples and keep the ions in solution, prevent their adsorption and precipitation in solution as well as bacterial growth. Labile parameters such as $\mathrm{pH}$, turbidity, temperature EC and TDS were determined in the field with the aid of hand held digital pH, Turbidity meter (Phep 98201), EC/TDS meter (Medfab 190), and a digital thermometer (CE 0434) for temperature. Field testing; "[29] of labile variables is essential if precise measurements of natural conditions are desired. Standard methods; "[30] the most probable number (MPN) approach was used to test for bacteria, while photometric and atomic absorption spectrophotometer (AAS) methods were used in analyzing the chemical parameters".

\subsection{Statistical Analysis of Data}

Result of laboratory tests were further subjected to numerical analysis using the water quality index (WQI). The WQI, "[31] is a unit-less number that expresses overall water quality at a certain location and time based on several water quality parameters for a specific and intended use of water". In other word, it is a technique of rating that provides the composite influence of individual water quality parameters on the overall quality of a water body, and this concept is useful in knowing the degree of water contamination at a particular period as well as comparing water quality across sources or location and time. The WQI evaluation is for human consumption hence, "permissible limit for the drinking water is 100 [32]". Therefore, WQI value greater than 100 is unfit for drinking, and Nigerian Standard for Drinking Water Quality 2015 was used as the benchmark. The weighted arithmetic water quality index method (WAWQIM);"[32] for easy of computation and understanding of results even by non-experts, flexibility in parameter selection and the most widely used method in developing countries where instrument of data collection is not robust enough for application of Delphi method" was use for index calculation.

$$
\text { Viz: WQI }=\sum \text { qiwi } / \sum \text { wi }=\sum\left(\left(\frac{1}{w i}\right) \times\left(\frac{C i}{S i} \times 100\right)\right) / \sum \text { wi }
$$

Where: $\mathrm{Ci}=$ Monitored value for every parameter, $\mathrm{Si}=$ maximum allowable limit for each parameter (standard), qi = quality rating for each parameter and wi $=$ relative weight of each parameter. The quality rating scale qi of each parameter is determined by dividing the monitored value $(\mathrm{Ci})$ by its respective standard $\mathrm{Si}$ and the result multiplied by 100 . Thus:

$$
\mathrm{qi}=(\mathrm{Ci} / \mathrm{Si}) \times 100
$$

The relative weight wi is determined by a constant $\mathrm{k}=1$ inversely proportional to the standard $\mathrm{Si}$ of the parameter (wi $=1 / \mathrm{Si}$ ). Lastly, the sub-index of every parameter was obtained by multiplying the quality rating (qi) by the relative weigh (wi), and the final WQI for each sample and source was obtained by lineal aggregation of all the sub-index values divided by the aggregate weight. 


\section{Results and Discussion}

\subsection{Physio-chemical and Microbial Characteristics of Rainwater Samples}

The physical parameters, colour, odour and taste were all unobjectionable, and $\mathrm{pH}$, turbidity, conductivity and total dissolve solids were also within limits (Table 1). The normal $\mathrm{pH}$ of 6.5-7.5 is attributed to absent of industries, low vehicular traffic and other anthropogenic activities that releases pollutants in the atmosphere, while turbidity of $1.8-2.7 \mathrm{mg} / 1$, colour, odour and taste was due to the frequent rain that wash away all dirt on catchments. Temperature ranged from $26.8-27.5^{\circ} \mathrm{C}$ with mean of $27^{\circ} \mathrm{C}$. Temperature of $15^{\circ} \mathrm{C}$ is more acceptable to consumers but higher temperature has no any health effect but can induce chemical reactions. Iron, an essential element in man nutrition and its deficiency causes goiter, ranged from $0.01 \mathrm{mg} / 1$ to $0.1 \mathrm{mg} / 1$ with mean of $0.05 \mathrm{mg} / \mathrm{l}$. Iron; "[32] above $0.3 \mathrm{mg} / \mathrm{l}$ does not have negative health effect but can impact colouration and corrode fixtures". An essential constituent for strong bone and tooth formation is calcium which ranged from $2-8 \mathrm{mg} / \mathrm{l}$, while magnesium ranged from $1-4 \mathrm{mg} / \mathrm{l}$. Calcium and magnesium above 75 and $20 \mathrm{mg} / 1$ respectively impact taste to drinking water. Nitrate ranged from $1.3-8.6 \mathrm{mg} / \mathrm{l}$ with mean of $3.6 \mathrm{mg} / \mathrm{l}$ is within limit, while chloride is between 10 and $32 \mathrm{mg} / 1$ with mean of 24 . When above $250 \mathrm{mg} / \mathrm{l}$ in drinking water chloride; "[33] impact salty taste and lead to rejection by consumers".

Fluoride concentration ranged from $0.001-0.002 \mathrm{mg} / \mathrm{l}$ with mean of $0.001 \mathrm{mg} / \mathrm{l}$. This is below the normal range of $0.05-1.5$ $\mathrm{mg} / \mathrm{l}$ for good health. Fluoride is beneficial; "[34] through reduction of dental decay and facilitation of proper bone development. However, deficiency or excess fluoride results in physiological disorders, skeletal and dental fluorosis". Fluoride; "[ $[35 ; 28]$ of up to $10 \mathrm{mg} / \mathrm{l}$ has been reported in groundwater in some parts of the study area due to hydrolysis of fluoride from fluoride occurring minerals in rocks by researchers". The low fluoride in rainwater can be to absent of anthropogenic activities like mining that exposes fluoride into atmosphere. Copper ranged from $0.01-0.1 \mathrm{mg} / 1$ with mean of $0.14 \mathrm{mg} / 1$ while zinc varied from $0.0-0.15 \mathrm{mg} / \mathrm{l}$ with an average of $0.37 \mathrm{mg} / \mathrm{l}$. Increase in zinc concentration was observed in old zinc roofing materials similar to results of rainwater quality; "[3] of Minna Nigeria". Manganese ranged from $0.0-0.02 \mathrm{mg} / 1$ with mean of $0.003 \mathrm{mg} / 1$. Manganese; "[37] above $0.2 \mathrm{mg} / \mathrm{l}$ causes undesirable taste and enhances bacterial growth". The concentrations of $\mathrm{Cr}$ and $\mathrm{Al}$ ranged from $0.01-0.01 \mathrm{mg} / 1$ and $0.01-0.06 \mathrm{mg} / 1$ with average of $0.001 \mathrm{mg} / 1$ and $0.031 \mathrm{mg} / 1$ respectively which are all within limits.

Toxic metals like $\mathrm{As}, \mathrm{Pb}$ and $\mathrm{Cd}$ were not detected just as pesticides and phenols. However; "[38] 3.0mg/l, $2.5 \mathrm{mg} / \mathrm{l}$ and $2.0 \mathrm{mg} / \mathrm{l}$ of $\mathrm{As}, \mathrm{Pb}$ and $\mathrm{Cd}$ respectively have been reported in surface water of the area. The absence of these metals indicates less effect of domestic waste. Similarly, feacal coliform and e-coli were not detected while total coliform was within limit. This is attributed to the period of sample collection, first week of September when rainfall has peaked with high intensity and quantity. At such period, all dirt and animal droppings on catchments have been completely washed away in addition to the observance of first flush. This result is similar to study in; "[39] Tanzania but at variance with that in; "[40] Canada".

Table 1. Statistical summary of physio-chemical and bacteriological parameter.

\begin{tabular}{|c|c|c|c|c|c|c|c|}
\hline Parameter & Min & Max & Mean & STD & Range & Variance & NSDWQ \\
\hline Temp & 26.8 & 27.5 & 27.0625 & 0.244584 & 0.7 & 0.059821 & $\mathrm{Amb}$ \\
\hline $\mathrm{pH}$ & 6.5 & 7.8 & 7.13 & 0.416467 & 1.3 & 0.173444 & 8.5 \\
\hline Turbidity & 1.8 & 2.7 & 2.73 & 1.026374 & 0.9 & 1.053444 & 5 \\
\hline Conductivity & 20 & 30 & 26.1 & 10.69216 & 10 & 114.3222 & 1000 \\
\hline TDS & 10 & 15 & 13.5 & 5.29675 & 5 & 28.05556 & 500 \\
\hline Hardness $\left(\mathrm{caco}_{3}\right)$ & 5 & 10 & 6.5 & 1.95789 & 5 & 3.833333 & 150 \\
\hline Calcium $\mathrm{Ca}^{2+}$ & 2 & 8 & 9.53 & 7.701955 & 6 & 59.32011 & 75 \\
\hline Sulphate, $\mathrm{SO}_{4}^{-}$ & 1 & 7 & 3.82 & 3.375006 & 6 & 11.39067 & 100 \\
\hline Nitrate $\mathrm{NO}_{3}^{-}$ & 1.3 & 8.6 & 3.64 & 3.112412 & 7.3 & 9.687111 & 50 \\
\hline Iron $\mathrm{Fe}^{2+}$ & 0.01 & 0.15 & 0.048 & 0.047563 & 0.14 & 0.002262 & 0.3 \\
\hline Chloride Cl- & 10 & 32 & 24 & 7.149204 & 22 & 51.11111 & 250 \\
\hline Fluoride F- & 0.001 & 0.002 & 0.0013 & 0.000483 & 0.001 & 2.33E-07 & 1.5 \\
\hline Copper $\mathrm{Cu}^{2+}$ & 0.01 & 0.2 & 0.143 & 0.218482 & 0.19 & 0.047734 & 1 \\
\hline Zinc $\mathrm{Zn}^{2+}$ & 0 & 1.5 & 0.376 & 0.588221 & 1.5 & 0.346004 & 3 \\
\hline Manganese $\mathrm{Mn}^{+}$ & 0 & 0.02 & 0.0034 & 0.005873 & 0.02 & $3.45 \mathrm{E}-05$ & 0.2 \\
\hline Lead $\mathrm{Pb}^{+}$ & 0 & 0 & 0 & 0.000422 & 0 & $1.78 \mathrm{E}-07$ & 0.01 \\
\hline Aluminium $\mathrm{Al}^{+}$ & 0.01 & 0.06 & 0.031 & 0.015239 & 0.05 & 0.000232 & 0.2 \\
\hline Chromium $\mathrm{Cr}^{+}$ & 0.01 & 0.01 & 0.01 & 0.012867 & 0 & 0.000166 & 0.05 \\
\hline Cadmium $\mathrm{Cd}^{+}$ & 0 & 0.00 & 0.000 & 0.000516 & 0 & $2.67 \mathrm{E}-07$ & 0.003 \\
\hline Phenols & 0 & 0 & 0 & 0 & 0 & 0 & 0.001 \\
\hline Pesticides & 0 & 0 & 0 & 0 & 0 & 0 & 0.01 \\
\hline Total Coliform & 0 & 4 & 1.1 & 1.523884 & 4 & 2.322222 & 10 \\
\hline Faecal Colifom & 0 & 0 & 0 & 0 & 0 & 0 & 0 \\
\hline E-Coli & 0 & 0 & 0 & 0 & 0 & 0 & 0 \\
\hline
\end{tabular}




\subsection{Water Quality Index}

Index values of individual water sample (Table 2) ranged from 2 to 12 which show excellent water quality suitable for drinking. Besides, all biological parameters tested were within limits. Similarly, the overall calculated water quality index for the whole study (Table 3 ) is 4.7 also indicating excellent rainwater quality.

Table 2. Water quality classification based on calculated WQI value.

\begin{tabular}{|c|c|c|c|}
\hline WQI Value & Category & Number of Sample & Percentage \\
\hline$<50$ & Excellent & 10 & $100 \%$ \\
\hline $50-100$ & Good water & Nil & $0 \%$ \\
\hline $100-200$ & Poor water & Nil & $0 \%$ \\
\hline $200-300$ & Very poor water & Nil & $0 \%$ \\
\hline$>300$ & Unsuitable for human & Nil & $0 \%$ \\
\hline
\end{tabular}

Table 3. Summary of Computed Rainwater Quality Index Values.

\begin{tabular}{|c|c|c|c|c|c|c|}
\hline Parameter & Mean (Ci) & NSDWQ (Si) & $\mathbf{C i} / \mathbf{S i}$ & qi & Wi & qiwi \\
\hline $\mathrm{pH}$ & 7.13 & 8.5 & 0.838824 & 83.88235 & 0.117647 & 9.868512 \\
\hline Turb & 2.73 & 5 & 0.546 & 54.6 & 0.2 & 10.92 \\
\hline EC & 26.1 & 1000 & 0.0261 & 2.61 & 0.001 & 0.00261 \\
\hline TDS & 13.5 & 500 & 0.027 & 2.7 & 0.002 & 0.0054 \\
\hline $\mathrm{CacO}_{3}$ & 6.5 & 150 & 0.043333 & 4.333333 & 0.006667 & 0.028889 \\
\hline $\mathrm{Ca}$ & 9.53 & 75 & 0.127067 & 12.70667 & 0.013333 & 0.169422 \\
\hline $\mathrm{Mg}$ & 2.1 & 20 & 0.105 & 10.5 & 0.05 & 0.525 \\
\hline $\mathrm{SO}_{4}$ & 3.82 & 100 & 0.0382 & 3.82 & 0.01 & 0.0382 \\
\hline $\mathrm{NO}_{3}$ & 3.64 & 50 & 0.0728 & 7.28 & 0.02 & 0.1456 \\
\hline $\mathrm{Fe}$ & 0.048 & 0.3 & 0.16 & 16 & 3.333333 & 53.33333 \\
\hline $\mathrm{Cl}$ & 24 & 250 & 0.096 & 9.6 & 0.004 & 0.0384 \\
\hline $\mathrm{F}$ & 0.0013 & 1.5 & 0.000867 & 0.086667 & 0.666667 & 0.057778 \\
\hline $\mathrm{Cu}$ & 0.143 & 1 & 0.143 & 14.3 & 1 & 14.3 \\
\hline $\mathrm{Zn}$ & 0.376 & 3 & 0.125333 & 12.53333 & 0.333333 & 4.177778 \\
\hline $\mathrm{Mn}$ & 0.0034 & 0.2 & 0.017 & 1.7 & 5 & 8.5 \\
\hline As & 0 & 0.01 & 0 & 0 & 100 & 0 \\
\hline $\mathrm{Pb}$ & 0.0002 & 0.01 & 0.02 & 2 & 100 & 200 \\
\hline $\mathrm{Al}$ & 0.031 & 0.2 & 0.155 & 15.5 & 5 & 77.5 \\
\hline $\mathrm{Cr}$ & 0.021 & 0.05 & 0.42 & 42 & 20 & 840 \\
\hline $\mathrm{Cd}$ & 0.0006 & 0.003 & 0.2 & 20 & 333.3333 & 6666.667 \\
\hline Phen & 0 & 0.001 & 0 & 0 & 1000 & 0 \\
\hline Pest & 0 & 0.01 & 0 & 0 & 100 & 0 \\
\hline \multirow[t]{2}{*}{$\mathrm{TC}$} & 1.1 & 10 & 0.11 & 11 & 0.1 & 1.1 \\
\hline & & & & & 1669.191 & 7887.378 \\
\hline
\end{tabular}

$$
\mathrm{WQI}=\frac{\sum q i w i}{\sum w i}=7887.378 / 1669.191=4.7
$$

\subsection{Usability of the Rainwater for Human Consumption}

Drinking water suitability is always measured by two criteria's viz: the water should be free from any substance that may pose health risk, while the taste, odour and color must also be acceptable to consumers. Thus, these criteria's must be met for any water body to be considered suitable for human consumption. The results of this study show both health and acceptability parameters analyzed were within acceptable limits. This implies that rainwater of the study area is safe and acceptable for residents consumption. The complete absence of industries, less vehicular traffic and other anthropogenic activities such as mining, excessive burning etc that may release hazardous gases into the atmosphere air and in turn pollute rainwater significantly contributed to low chemical and/or metal content of the rainwater samples. This result is similar; "[24] to a study in Zanzibar Island, Tanzania that found physio-chemical parameters of rainwater all within limits due to absence of environmental influence. But; " $[9,15]$ contrary to Jos and South-South region of Nigeria."

Similarly, non-leaching of catchment materials and period of sample collection is observed to have contributed positively in having good rainwater quality. The non-leaching of catchments is due to non-coating of the materials with toxic metals, new age of most catchment materials, climate of the area and non-acidic nature of rainwater. This result is similar to "Ibadan Metropolis with suitable water for drinking due to absence of leaching of roof materials...[41]" but contrary; "[22] to that of Enugu". The good bacteriological quality of the rainwater to the period of sample collection, first week of September when rainfall had peaked with high intensity and quantity. At such period, all dirt on catchment is been completely washed away and the rainfall frequency does not allow any time lapse between rain events for dirt to accumulate on the catchments. Moreover, the observance of first flush also assisted in washing dirt may have gathered on catchments which are also similar to results 
of studies in; "Tanzania and Canada [39, 40]".

\section{Conclusion and Recommendations}

The study identified zinc and aluminium rooftops as the major catchments for rainwater harvesting in the study area. All biological parameters tested were within acceptable limits and $100 \%$ samples have excellent water quality index. The overall WQI is 4.7 also indicating excellent rainwater quality. Parameters like colour, odour and taste which are not included in index determination show unobjectionable results. Therefore, the study concluded that rainwater of the study area is suitable for human consumption.

The absence of industries and mining sites in the area, none leaching of catchment materials, the time of sample collection at the peak of rainy season and the observance of first flush are responsible for good rainwater quality of the study area. Therefore, regular catchment maintenance to prevent biological contamination with animal feaces and observance of flush are recommended. Caution should be exercise in using water from old zinc catchments due to the observed increase in zinc concentration with age of materials. Besides, further research should be undertaken to increase the sample size and also compare quality of rainwater from new and old catchments so as to broaden the scope of this topic and the benefit therefrom.

\section{References}

[1] Gleick, P., H. (1999). The human right to water. Water Policy 1 (5), 487-503.

[2] UN (2017). World Water Development Report. Wastewater: The Untapped Resource. UNESCO, Italy. Retrieved October 3rd 2018 from: www.unesco.org/water/wwap.

[3] Falkenmark, M. (2013). Growing water scarcity in agriculture: future challenge to global water security. Philosophical Transactions of the Royal Society. A 371: 20120410. http://dx.doi.org/10.1098/rsta.2012.0410.

[4] Gongden, J. J., \& Lohdip, Y. N. (2009). Climate change and dams drying: A case study of three communities in Langtang South of Plateau State, Nigeria. African Journal of Natural Science, 8 (12), 37-43. Doi: 10.2495/WRM150251.

[5] Dallman, S., Chaudhry, A. M., Muleta, M. K., \& Lee, J. (2016). The Value of rain: Benefit-cost analysis of rainwater harvesting systems. Water Resources Management, 30 (12), 4415-4428. https://doi.org/10.1007/s11269-017-1798-z.

[6] Saidu, B. J., Jidauna, G. G., Sanusi, J. K., \& Dabi, D. D. (2019). The Contribution of Zobe Dam to the Socio-Economic Development of Makera Community Dutsinma Local Government Area, Katsina State North-Western Nigeria. International Journal of Environmental Monitoring and Analysis, 7 (3): 75-82. Doi: 10.11648/j.ijema. 20190703.13.

[7] Aladenola, O., \& Adeboye, O. (2018). Assessing the Potential for Rainwater Harvesting. Water Resources Management, 24 (10), 29-37. doi: 10.1007/s11269-009-9542-y.

[8] Amponsah, N., Bakobie, N., Cobbina, S. N., \& Duwiejuah, A.
B. (2017). Assessment of Rainwater Quality in Ayanfuri, Ghana. American Chemical Science Journal, 6 (3), 172-182. DOI: $10.9734 / \mathrm{ACSj} / 2015 / 15881$.

[9] Nangbes, J. G., Wufem, B. M., Shamle, N. J., \& Nvau, J. B. (2014). Concentration and distribution of inorganic ions in rainwater of Jos and Bukuru Metropolis, Plateau State, Nigeria. IOSR Journal of Applied Chemistry (IOSR-JAC), 7 (7), 15-25. Retrieved September 5th 2016 from: www.iosrjournals.org.

[10] Chukwuma, E. C., Nzediegwu, C., Umeghalu, E. C., \& Ogbu K., N. (2016) Quality assessment of direct harvested rainwater in parts of Anambra State, Nigeria. Hydrology for Disaster Management: Special Publication of the Nigerian Association of Hydrological Sciences. Retrieved April $11^{\text {th }}$ from: journl.unaab.edu.ng/index.php/NAHS /article/view/928.

[11] Egwuogu, C. C., Okeke, H. U., Emenike, H. I., \& Abayomi, T. A. (2017). Rainwater quality assessment in Obio/Akpor LGA of River State Nigeria. International Journal of Science and Technology, 5 (8), 374-381.

[12] Jamal, R., Kamel, A., Adnan, A., Rida, A. (2015). Quality Assessment of Harvested Rainwater for Domestic Uses. Jordan Journal of Environmental and Earth Sciences, 2 (1), 26-31.

[13] Zhang, Q., Wang, X., Hou, P., Wan, W., Li, R., Ren, Y., \& Ouyang, Z. (2014). Quality and seasonal variation of rainwater harvested from concrete, asphalt, ceramic tile and green roofs in Chongqing, China. Journal of Environmental Management, 132, 178-187.

[14] Emerole, C. O., \& Emerole, C, G. (2015). Urbanisation and quality of harvested rainwater in Owerri, Imo State, Nigeria. International Journal of Multidisciplinary Research and Development 2 (11), 406-410. Retrieved April 202017 from: www.allsubjectjournal.com.

[15] Godwin, A. E., Helen, S. E., Cyril, I. E., \& Emmanuel, U. D. (2016). Impact of human activities on rainwater quality in South-South Region of Nigeria. Journal of Applied Life Sciences International, 9 (3), 1-11. DOI: 10.9734/JALSI/2016/29762.

[16] Uzomaka C, O., Titilope, J. J., Alaba, J. A., \& Ilemobayo, I. O. (2014). Environmental Implications and Significance of Rainwater Harvested from Lagos, Southwest Nigeria. Journal of Environmental Analytical Chemistry, 2 (1), 1-8. DOI: 10.4172/2380-2391.1000118.

[17] Simmons, G., Hope, V., Lewis, G., John, W., \& Gao, W. (2015. Contamination of potable roof-collected rainwater in Auckland, New Zealand. Water Research, 35 (6), 1518-1524.

[18] Gwenzi, W., Dunjana, N., Pisa, C., Tauro, T., Tope, N., \& Nyamadzawo, G. (2015). Water quality and public health risks associated with roof rainwater harvesting systems for potable supply in Ghana. Sustainability of Water Quality and Ecology, 3 (5), 44-52. http://dx.doi.org/10.1016/j.swaqe.2015.01.006.

[19] Basak, B., \& Algha, O (2016). Trace metals solubility in rainwater: Evaluation of rainwater quality at a watershed area, Istanbul. Environmental Monitoring and Assessment 167, 493-503. DOI: 10.1007/s10661-009-1066-7.

[20] Bello, M \& Nike, M. (2015). Rainwater harvesting, quality assessment and utilization in kwali area, FCT Abuja. Journal of Engineering and Technology (JET), 10 (2), 60-69. Retrieved March 232018 from: www. bayerojet.com. 
[21] Rahman, S., Khan, M. T. R., Shatirah, A., Nazli, B. C. D., S. Biswas, S. K., \& Shirazi, S. M. (2016). Sustainability of rainwater harvesting system in terms of water quality. The Scientific World Journal. 1-2. http://dx.doi.org/10.1155/2014/721357.

[22] Olaoye, R. A., Olaniyan, O. S. (2012). Quality of rainwater from different roof material in Enugu, Nigeria. International Journal of Engineering and Technology, 2 (8), 1413-1421.

[23] Osunkiyesi, A. A., Olawunmi, M. O., Soyemi, O. S., Okibe, O. D. (2016). Effects of materials and the age of roofing sheets on the quality of harvested rainwater in Totoro Abeokuta, Ogun State Nigeria. IOSR Journal of Applied Chemistry (IOSR-JAC), 9 (9), 64-69. DOI: 10.9790/57360909026469.

[24] Abdul, A. J. M., Haji, M., Ibrahim, A., Lim, L. H., \& Hassan, R. A. (2016) Determination of physico-chemical parameters in rainwater in urban-west region of Zanzibar Island, Tanzania. ARPN Journal of Science and Technology, 6 (2), 55-59. Retrieved July, 3rd 2017 from: http://www.ejournalofscience.org.

[25] Ahmed, W., Hodgers, L., Sidhu, J. P. S., \& Toze, S. (2012) Fecal indicators and zoonotic pathogens in household drinking taps fed from rainwater tanks in Southeast Queensland, Australia. Applied Environmental Microbiology, 79 (12), 3762-3769.

[26] Bukar, W. M. (2014). Physicochemical and bacteriological qualities of harvested rainwater in Maiduguri metropolis, Borno State. In J. A. Ijere., M. Waziri., \& A. K. Monguno, (eds.). Geography and Challenges of Development in Nigeria, Proceedings of the 55h Annual Conference of Association of Nigeria Geographers (ANG): Department of Geography, University of Maiduguri.

[27] Ochuko, M. O. (2016). Harvested Rainwater Quality: A Case Study of Aule in Akure, South Western Nigeria. European Scientific Journal, 12 (11), 451-461. Doi: 10.19044/esj.2016.v12n11p451.

[28] Dibal, H. U., Schoeneich, K., Lar, U. A., Garba, I., Lekmang, I. C., \& Daspan, R. I. (2016). Hydrochemical appraisal of fluoride in groundwater of Langtang area, Plateau State, Nigeria. Global Journal of Geological Sciences 14, 23-39. http://dx:doi.org/10:4314 /gjgs.v14i1.3.

[29] Tebbut, T. H. Y. (1992). Priciples of water quality control, fouth edition. Oxford Pargamon Press. 73-251.

[30] USEPA (2012). An introduction to water quality monitoring. Retrieved Sepember 10th 2017 from: http://www.water.epa.gov/type/watersheds/monitoring/monintr .cfm.
[31] Abbasi, T., \& Abbasi, S. A. (2014). Water quality indices. Environmental Earth Science, 7, 4625-4628. DOI: 10:1007/s12665-014-3141-9.

[32] Amadi, A. N., Okunlola, I. A., Dan-Hassan, M. A., Aminu, T., \& Ola, O. (2015). Evaluation of groundwater quality in shallow aquifers in Minna, North-Central Nigeria using pollution load index. Journal of Natural Science Research, 5 (8), 45-57. Retrieved August 6th 2017 from: http://www.iiste.org.

[33] WHO (2011) Guidelines for Drinking Water Quality, 4th ed. vol. 1, Recommendations. Geneva; Author. Retrieved April 7th 2017 from: http://www.who.int.

[34] Fordyce, F. M (2011). Fluorine human health risks. In: Nriagu J. O (ed.) Encyclopedia of Enviromental Health, 2, 776-785. Elservier EH7 3LA: Burligton.

[35] Dibal, H. U., Schoeneich, K., Garba, I., Lar, U. A., \& Bala, E. A. (2012). Occurrence of fluoride in the drinking waters of Langtang area, north central Nigeria. Health, 4 (11), 11161126. http://dx.doi.org/10.4236/health.2012.411169.

[36] Musa, J. J., Anijiofor, S. C., Saidu, M., \& Bake, G. G (2013). Effects of roofing materials on harvested rainwater quality in Minna, Nigeria. International Journal of Basic and Applied Science, 01 (03), 548-563.

[37] Jidauna, G. G., Dabi, D. D., Saidu, B. J., Ndabula, C., \& Abaje, I. B. (2014a). Chemical water quality assessment in selected location in Jos, Plateau State, Nigeria. Research Journal of Environmental and Earth Sciences 6 (5), 284-291.

[38] Gongden, J. J., \& Lohdip, Y. N. (2015). Seasonal water quality variation of two dams in Plateau State, north-central Nigeria. Water Resources Management VIII, 196, 291-305. Doi: 10.2495/WRM150251.

[39] Despins C, Farahbakhsh K, Leidl C, (2019). Assessment of rainwater quality from rainwater harvesting systems in Ontario, Canada. Journal of Water Supply: Research and Technology-AQUA 58 (2), Pp 117-134.

[40] Mayo, A. W., \& Mashauri, D. A. (2019). Rainwater harvesting for domestic use in Tanzania a case study: university of Dar Es Salaam staff houses. Water International 16 (1), 2-8. http://dx.doi.org/10.1080/02508069108686093.

[41] Adetayo, A. O., \& Aduramigba-Modupe, V. O. (2013). Quality assessment of rainwater harvested through different roof types in of Part Ibadan Metropolis, Nigeria. Earth Resources, 1 (3), 60-63. DOI: 10.12966 /er.09.01.2013. 